\title{
The Western Populist Right in 2020: A Purported Clash Between the Public Good and Individual Rights
}

\section{The Pandemic and Citizens' Rights}

The current world health crisis has brought forth with major strength the debate over the boundaries of constitutional rights and freedom. A question that was often discussed during the first months of the pandemic, in newspapers' op-eds in the United States as well as in Europe, asked whether social distancing measures constituted essential precautions, or attempts made by states and governments at curtailing citizens' rights.

The impact of the COVID19 pandemic on the world's population, physically, but also mentally and spiritually, can hardly be overestimated. It didn't therefore cause surprise the widespread deployment of religious tools to cope with the feelings of fear and uncertainty on the part of faithful individuals (Bentzen 2020, Molteni et al. 2020). To halt the spread of the then unknown deadly virus, however, governments around the world imposed more or less severe restrictions on public gatherings, including religious and spiritual ones (Baumgardner 2021, Mazurkiewicz 2021).

With an intensity varying from country to country, the clamor that these restrictions created in the conservative public discourse is indicative of how the western populist right increasingly exploits these feelings of uncertainty, as well as the desire of affected populations for connection and reassurance, to build and strengthen their case against a more communitarian state apparatus and inclusive policies. In other words, public political figures' remonstrations against restrictive measures, also involving religious gatherings, shed light on how religious identity and belonging are exploited for the advancement of political and ideological claims.

These claims, far from being aimed exclusively at pursuing a conservative political agenda lamenting possible interferences from an intrusive government, foster the perception of a public fight between defenders and enemies of constitutional rights, such as the one to religious freedom and freedom of speech (Dudas 2005, Jelen 2005, Jelen et al. 2018, Lewis 2017). Furthermore, they facilitate the rhetorical and ideological transfer of instances of behavioral guidelines directed at preserving the public good into an arena of sterile, polarized political and public discourse (Glendon 2008).

This paper deals with said discourse, deployed during the first months of the COVID19 pandemic by prominent conservative politicians and ideologically aligned media outlets and interest groups. The discourse taken into consideration depicts alleged infringements on citizens' constitutional rights. As the paper highlights, in fact, the preeminent spot granted to concepts such as religious freedom, on the part of actors of the western populist right, is effectively inserted in political agendas aimed at ideologically asserting the superiority of an almost exclusively white identity, characterized by the adherence to the Christian religion, against the perceived threat posed by outgroups (Wodak 2015).

The paper takes into consideration recent developments of the western populist right, focusing on its protagonists active in the United States and their European counterparts, in particular the Italian case. Albeit radically different in many aspects of political, social, and public life, the two countries on which the present paper focuses present a common trait consisting in the crucial role assumed by religion in the life of many citizens.

The analysis is aimed at highlighting both the common traits and the peculiarities of the observed cases, and considerable attention is dedicated to the exposition of how the 
conservative discourse based on the protection of individual rights of religious citizens is geared toward the assertion of a racially defined, supposedly legitimate and core nationhood.

\section{The Western Christian Populist Right}

Donald Trump's conquest of the Oval Office in 2016 spurred the growth of a flourishing literature investigating the growth of rightwing populist parties in western democracies. A specific current of these studies focuses on the role of Christian religion (Protestant or Catholic) in fostering support for what can be seen as a concerning renaissance of ethnocentrism and authoritarianism (Giebler and Werner 2020, Martì 2019, Migliori 2020, Rozell, 2018, Whitehead et al. 2018).

If the entanglement of Christian religion and politics in the United States has been systematically documented by scholars investigating the activity of the Religious Right since the end of the 1970s, the interest surrounding the exploitation of Christianity on the part of European political actors has undergone a dramatic growth in more recent times (Montgomery and Winter 2005, Mudde 2007, Vieten and Poynting 2016, Wodak et al. 2013), with a particular focus on eastern European states on the verge of becoming authoritarian regimes (Coakley 2021, Kovács 2021, Walker 2019).

Western democracies situated on both sides of the Atlantic Ocean clearly present substantial differences in terms of historical development, political systems, and (dislestablishment of religion. This, however, has not hindered the attempts at creating a transatlantic rightwing Christian populist network of social and political actors. Moreover, the structural differences among these countries cannot hide striking similarities with regard to the background of the rising stars of the western populist right, as well as to the characteristics of its electorate.

A commonality that is to be observed with regard to the political sphere is the rise of a class of actors whose previous or early public life all but suggests whatsoever entanglement with religiosity, and who reinvented themselves as defenders of what large swaths of the electorate consider the unofficially sanctioned state religion. This process allowed them to dramatically expand their support or voting base, thus demonstrating the efficacy of leveraging on religious belonging in public discourse.

The year 2020 has brought upon the world the spread of a pandemic disease which has had far reaching consequences not only on the lives of billions of individuals, but also on the ideological and political realms which are an inevitable part of our existence. Within these spheres, and amidst this twenty-first century first global-scale public health crisis, the western populist right has found a suitable spot for reasserting a stronghold of its ideology: the purported threat to individual constitutional rights.

Leveraging on the discontent engendered by the ban imposed on the gathering of people, even for spiritual purposes, to safeguard the public good, prominent actors on both sides of the Ocean rode a wave of resentment and fear to advance a discourse based on the supposed threat posed by the state to the rights of Christian citizens. In doing so, these actors allowed Christian symbols to become a fixture of rightwing populism across the western world.

Key rightwing populism's features such as nativism and authoritarianism (Lamour 2021) have not gone lost in the transition towards the growing inclusion of Christian symbols in the discourse of these political actors. They have in fact remained a staple of their agendas, highlighting the exploitation of Christian symbols in what has been defined a developing 
western post-religious right being "politically, culturally and often sociodemographically opposed to Christian beliefs and institutions" (Cremer 2021, 16).

This is then mirrored by the electorate of the parties that can be ascribed to this ideology, as citizens being appealed by this type of post-religious right can often be defined as only nominally Christians (Edgell 2017). These voters, moreover, in particular in Europe, are in many respects different from the traditional electorate of older Christian democratic parties, also with regard to their infrequent church attendance (Montgomery and Winter 2015).

\section{COVID19 and Religious Freedom in the United States}

In April 2020, a few days before Easter, the Kansas Supreme Court reinstated a measure, implemented by the Democratic governor Laura Kelly, banning religious gatherings of more than ten people. Kelly had to resort to the Supreme Court's intervention because her decision, taken as a consequence of the dramatic spread of the pandemic, had almost immediately been revoked by the state's Republican legislators who had harshly criticized it as an unacceptable attack to religious freedom.

Cases like this were not uncommon during the first months of the pandemic in the United States where, alongside the fight against the virus in overwhelmed hospitals, other battles were fought, specifically between the federal and state governments, with courts called in to settle cases allegedly involving infringements on the First Amendment (Buchanan 2021).

Despite the number of protests against restrictions imposed on religious gatherings, an August 2020 Pew Research Center's Poll found that "U.S. adults overwhelmingly say houses of worship should be required to follow the same rules about social distancing and large gatherings as other organizations or businesses in their local areas. About eight-in-ten Americans (79\%) take this position [...]" (Pew Forum 2020). This finding, however, should be observed in light of the fact that, as of late April 2020, only ten states had imposed restrictions on religious assemblies, with the rest of the states only imposing a maximum number of participants (Villa 2020).

The Religious Liberty Institute at Andrews University in Michigan issued a Religious Liberty and COVID-19 Research Project warning for the risk of rising "civic disaffection, disorder, and conflict" (4) possibly engendered by excessively restrictive measures taken by states or the government. As the report continues, "However, when public authorities demonstrate respect for religious persons and communities, this can foster civic trust between religious communities and the state, leading to greater levels of cooperation with religious leaders in communicating effectively regarding public health guidelines, vaccine education, and other public health actions" (id.).

What is lamented, then, is the seeming lack of communication between what is seen as an overbearing state apparatus, and the real needs of the citizenship which then becomes almost legitimated in its rejection of restrictive measures.

Religious Right interest groups, portraying themselves as the joining link between citizens' values and demands and the government, were not immediately enraged about restrictions on religious gatherings. Tony Perkins' Family Research Council (FRC), one of the most prominent Religious Right organization, initially supported stay-at-home orders, but their tone changed abruptly when New York's mayor De Blasio realized that the provision was not universally respected and had to resort to more stringent measures. 
It was what came next that has Americans everywhere up in arms. If the city's houses of worship don't comply, the mayor threatened, New York officials will "take additional action up to the point of fines and potentially closing the building permanently... You've been warned." Where are we? Communist China? As frustrated as de Blasio is with the situation, this is a completely disproportionate response -- not to mention an unconstitutional one. No mayor has the authority to permanently close the doors of a city's churches and synagogues. And if he tried, there's a little thing called the First Amendment that would have something to say about it (Perkins 2020a).

The Trump-Pence administration often applauded protests or the acts of pastors overtly defying restriction orders. The former Vice President publicly applauded the Department of Justice's support of a Virginia church refusing to limit the service audience to ten participants (Kuhrana 2020).

In the midst of the worst months of the pandemic, President Trump immediately sided with protests against church restrictions (Gjelten 2020, Gearan et al. 2020). In the most critical weeks of the virus spread in his country, Trump showed a lack of cohesion and a national plan to address the health crisis. The former president issued guidelines from the White House, only to then incite citizens protesting social distancing measures and urge state governors to loosen controls.

This attitude of defiance of governors and symbolic alignment with citizens' claims continued, although for a different reason, in May and June 2020, when the killing of George Floyd by the Minneapolis police and the ensuing protests against the plague of racism momentarily took the place of the pandemic among national concerns. Trump sided with the citizens criticizing the protesters' seemingly unpeaceful methods and repeatedly spurred state governors not to hesitate to resort to violent repression if necessary.

On both occasions, FRC did not hesitate to reiterate support for Donald Trump. In a Washington Update published on April 2, 2020, Perkins explained how the president was aware of the threat posed by COVID19 well before it exploded across the country. The blame for the delays in the restrictive measures was thus placed on all those who, particularly in the final weeks of 2019, became distracted by the impeachment proceedings and ignored the looming global threat from China.

Reporting the testimony of Tom Cotton, a Republican senator from Arkansas, who allegedly tried to alert the White House to the situation in China well before the pandemic broke out, Perkins defined Democrats the group "[whining] and [complaining] about the president's handling of the pandemic" and claiming that "[while] Congress may have been distracted, thank goodness the president wasn't" (Perkins 2020b). Perkins did not specify how Trump demonstrated that he had heard the words of those warning of the impending catastrophe as early as December 2019 and January 2020, and went on to assert China's utter unreliability, demonstrated by its lack of transparency in reporting actual data regarding the health crisis.

Finally, following the protests generated by the killing of George Floyd, Perkins sent an email requesting donation to continue fighting for the freedom of religion for American citizens. While acknowledging the inherent gravity of Floyd's killing, Perkins argued that what Americans needed most in the midst of the health crisis were more opportunities for prayer. This, however, could not occur, as "an alarming number of governors and mayors, as well as a 
few judges, have used the coronavirus crisis to infringe upon our First Amendment rights to religious freedom and to assemble" (Perkins 2020c).

What emerges from the words of Perkins is the unconditional support to the figure of a president who made of his being an outsider of the American political system a staple of his figure. Donald Trump's populism, in fact, was not only embodied in the slogan "America first", but also in his continuous expression, mainly via Twitter, of support for the claims of citizens who felt damaged by the interests of elites and intellectuals (in this case those who demanded caution against the expanding virus) and limited in their constitutional rights and freedoms.

The year 2020 also saw the end of the four-year period in which Trump assumed the office of president also thanks to an unprecedented support on the part of white conservative Christian voters. In October 2016, just over a month before the presidential election, Christian nationalism scholar Philip S. Gorski wondered the following: "Why would white evangelicals pull the lever for a man who is the walking antithesis of most everything they claim to stand for - family values, piety, humility, and forgiveness?" (Gorski 2017, 338).

The multitude of analyses and answers that this question received in the past five years can be summarized in the concise explanation that, for many of the voters who define themselves evangelicals, identifying as Christian represents, rather than a series of dogmas to follow or teachings on which to model one's life, only one of the facets of an identity perceived as seriously threatened by factors such as immigration, modernization of society, diversification of the demographic composition of the country, and achievements in the struggles for the civil rights of minorities.

Already at that time, in fact, Gorski provided an answer that went in the direction just outlined, when he defined Trumpism as "a secularized version of white Christian nationalism" $(2018,361)$ : a subspecies of nationalism that relies on church belonging to establish membership, or foreignness, to the nation in question.

Donald Trump was not the figure that made the world realize the entanglement of Christian religion and conservative politics in the United States. What his success among white "Christianists" (Gorski 2018, 362) revealed, however, was the effectiveness of a shallow, sloganized deployment of religious symbols to foster support for populist, authoritarian, nativist policies. Much like his European counterparts.

\section{COVID19 and Religious Freedom in Italy}

Constituting the first European hotspot of the COVID19 pandemic, Italy was immediately interested by the necessary restrictions imposed on all types of public gatherings, implemented alongside a particularly severe form of shelter-in-place dispositions.

In April 2020, the Thematic Group on Human Rights of the Conference of European Churches (CEC) issued a reflection on the social distancing measures being taken, claiming that "[the] prohibition of Easter celebrations in churches is just one example of far-reaching restrictions on the exercise of many human rights and civil liberties world-wide" but that these, however "are part of an effort to make physical distancing effectively prevent personto-person infections" (CEC 2020).

Moreover, the CEC declared that "[whilst] in times of persecutions, massacres and genocides, and even previous pandemics, churches have been places of refuge and consolation for many believers, it is important to acknowledge that the prohibition of assemblies, including services, are not meant as religious discrimination and persecution. At 
present this measure is intended to safeguard human lives, both of the believers and of other members of society" (id.).

Not of the same opinion were prominent Italian rightwing parties, such as Lega (League) and Fratelli d'Italia (Brothers of Italy), which insisted on the reopening of churches and the restoration of in-presence masses, in contrast with the provisions of the decree-law issued on March 25, 2020.

Also during the Italian lockdown, scholars, in particular from the legal field, engaged in the debate over the possible infringement of constitutional rights caused by governmental provisions (Colaianni 2020, Licastro 2020). The tone of the reflections expressed concern for the possible exaggeration of restrictive measures, which, it was argued, should always be decided upon in close cooperation with religious leaders. This is necessary, it was suggested, to prevent their transformation in long-term restrictions permanently endangering religious freedom rights.

Matteo Salvini and Giorgia Meloni belong to the current of rising rightwing, populist, and authoritarian politics conquering growing numbers of the Italian electorate. Unsurprisingly, part of their programmatic discourse relies on the defense of an allegedly threatened Christian identity. Their discourse and ideology pick up the legacy of a rightwing current born with the founding of Democrazia Cristiana (Christian Democracy) in 1943 and from then on proliferated, split and reconstituted into various other entities, all the while maintaining the element of the defense of a Christian identity, Catholic more precisely, as a reaction to multiculturalism, modernization, women's emancipation and immigration.

The League is an evolution of the former Northern League born at the end of the 1980s, which had as its main aim the defense of a traditional northern Italian identity also defined by adherence to the Catholic faith (Guolo 2011, Miccoli 2012). Its newest version originated in 2013 and is guided by Salvini. Brothers of Italy, born in 2012, is represented by Meloni; its symbol is a flame colored as the Italian flag, a clear reference to the Movimento Sociale Italiano (Social Italian Movement), an overtly fascist party created in 1946 by former Mussolini acolytes.

Salvini was recently indicted for prohibiting Open Arms, a ship carrying refugees, from entering the port of Lampedusa in 2019, and, in line with his most famous predecessor leading the Northern League Umberto Bossi, impersonates the staunchest opposer to the rights of immigrants landing on Italian coastlines. Finally, Meloni often mixes the defense of the culture of life with affirmations against the so-called islamization of Europe (Agi 2019).

Although counting on an ever-growing but at times impressively high, public consensus, neither of the two party-leaders ever gained the role of Prime Minister. Despite the constant and evident struggle to find and maintain a long-term political and programmatic common ground, the two figures present a striking commonality in their public approach to the instances of people of Catholic faith, an electoral basin both of them are aware they have to appeal to.

Italy lacks the unofficial but incisive movement known as Religious Right in the United States, but occasions for politicians to signal their alignment to the Catholic, or nominally Catholic, constituency clearly abound. Salvini has often made sure he was caught on camera carrying, and at times kissing, a rosary necklace, and one of Meloni's most famous public speeches (pronounced in 2019) saw her shouting from a stage to a cheering crowd "I'm a woman! I'm a mother! I'm a Christian!".

Salvini claimed that God has no interest in helping him gaining political victories, but in helping "Italy and Europe to find hope, pride, roots, job, and security" as it is in God's 
hands that rest "the future and destiny of a country and a whole continent" (An. C. 2019). Meloni, while participating in the March for Life in Rome in 2019, claimed that her party had decided to walk without political symbols and only behind a banner proclaiming "Dio, Patria, Famiglia" (God, Country, Family). Their efforts of wooing Christian electors didn't stop during the pandemic, and in April 2020, former Minister of the Interior Matteo Salvini invoked the protection of Mary upon the country, a protection which would have been assured had churches been left open.

These figures can count on the support of prominent conservative media outlets, but it is in La Nuova Bussola Quotidiana (The Daily Compass) that one can find the clearest signs of alignment to their Christian populist rightwing program. A self-proclaimed newspaper providing news from a Catholic point of view, The Compass is an online paper which, during the pandemic, represented the voices of those dissatisfied, or utterly furious, with governmental decisions to close churches. Starting from the law issued on March 25, 2020, the newspaper published article after article decrying the alleged infringement on religious freedom on the part of the government.

In an op-ed titled "Masses banned, religious freedom has died (yesterday in Parliament)," a newspaper's journalist claimed:

For the first time in the history of the Republic, the Italian Parliament, maintaining the letter $\mathrm{h}$ inserted in decree-law No. 19 of March 25, 2020, gives the green light to the limitation of religious freedom which - as recalled by a recent ruling of the Constitutional Court - being "guaranteed by Article 19 of the Constitution, is an inviolable right, protected to the highest degree by the Constitution" (Spuntoni 2020).

The newspaper also espouses the views of the currently growing population of anti-vax protesters, a faction unsurprisingly composed by many self-proclaimed fundamentalist Catholics (Marroni 2021), comparing the mandate to show proof of vaccination or a negative test to the persecutions enacted at the time of Nazism in Germany (Scandroglio 2021). ${ }^{1}$

The newspaper defines the pandemic an excuse to deal a blow to Catholic faith, or a new opportunity to do so, to be more specific, under the pretension of "safeguarding public health" (Zambrano 2021). ${ }^{2}$ The author lists a few of the most prominent cases of what are defined attacks to religious freedom but claims that they all ended in moderate public outcries. In Spain, instead, the activity of the Agency Monitoring Freedom of Religion and of Conscience has officially identified a disconcerting list of instances of curtailments of the citizens' religious freedom.

An overview of the archive of the newspaper's articles reveals how the pleads in defense of a supposedly imperiled religious freedom are coupled with several articles protesting a purported favoritism of the liberal world (comprising of political figures and artists among other actors) toward Islam, a grave threat to the Christian roots of Europe.

\footnotetext{
1 "Arbeit macht frei, work makes you free. It was the motto placed at the entrance of many Nazi concentration camps. Today we could replace work with the vaccine. [...] As Hannah Arendt reminded us, the evil is banal - it's like blackmailing: wanting to vaccinate everyone, the price to be paid to the state to continue to be free is the Green Pass and therefore the vaccine. The ideal citizen then becomes the slave of freedom" (Scandroglio 2021).

2 "In 2020, a new mode of attack on religious freedom has made its appearance. It is called "safeguarding public health" and it has become a picklock for limiting, when not actually closing, masses. In Europe and around the world, USA, Canada and Latin America especially, we have seen several cases. The Compass has reported in detail on numerous episodes of violation of the freedom of the faithful following the restrictions resulting from the lockdowns decreed by the Conte government" (Zambrano 2021).
} 
These articles are occasionally interspersed with editorials pondering on issues concerning the battle for LGBTQI+ rights, against what they deem the danger of gender ideology.

Finally, in line with the ideological development of a western Christian right network, the newspaper doesn't refrain from considerations on the political realm of other western democracies. On the occasion of the leaking of the tape in which Trump claimed that he could grab women by the pussy (sic.), The Compass argued that, if the GOP had abandoned Trump to his uncertain faith, a coalition of religious leaders surely had not. And that if these people were certainly aware that the then candidate was using them to attract religious voters, it was them using him to pass important policies (Respinti 2016). ${ }^{3}$

\section{The "Populist International"4}

The main figures of the Italian populist religious right are well inserted in the project of fostering the western populist right network initiated by former Trump's strategist Steve Bannon. This commonality of interests translated into a profitable exchange of participation, support and organization of events. Among these are the thirteenth World congress of families organized in Verona in March 2019, and the participation of Giorgia Meloni in the 2020 National Conservative Conference and in the annual U.S. Conservative Political Action Conference, CPAC, in 2019 and 2020.

In 2017, Bannon, in cooperation with Benjamin Harnwell, obtained concession of the Certosa di Trisulti in the region of Lazio, and established it as the seat of the Dignitatis Humanae Institute. ${ }^{5}$ This was supposed to become an academy for educating figures who wished to work for the protection and restoration of a Judeo-Christian west. After a long fight that saw civic organizations attempting to strip Bannon and Harnwell of the old monastery, and seemed to be ended in July 2021 with the official declaration that the Certosa was to be restituted to the Ministry of Culture, the ancient building still belongs to the $\mathrm{DHI}$.

But the project of what Mudde defines the "global Christian right" (2021) extends well beyond Italy. This is shown by the frequent interactions between key figures of the former Trump administration with Hungary's Orbán, as well as French, Austrian, and Spanish prominent rightwing political actors.

\section{Conclusion}

Exploiting the critical conjuncture created by the pandemic-imposed restrictions, western rightwing actors have once again portrayed themselves as the defenders and protectors of citizens' constitutional rights.

\footnotetext{
3 "Now only Christians, paradoxically, support Trump. After the now famous "sexist" video stolen from a microphone left on (by chance?) and spread by The Washington Post, the Republican Party (perhaps not looking forward to such an assist) has virtually abandoned the tycoon to his fate. But what the press [...] does not say is that the Christian Right has remained immovable at the side of the presidential candidate. [...] The Christian world, which has made itself available to the sorcerer's apprentice Trump, who has in turn made himself available to something greater than himself, sees in the elections of November 8 the possibility of being the instrument of a greater good" (Respinti 2016).

${ }^{4}$ Mudde 2021.

${ }^{5}$ Benjamin harnwell is director of the DHI and co-founded the European Parliament's Working Group on Human Dignity and worked on drafting the Universal Declaration of Human Dignity (http://www.dignitatishumanae.com/index.php/declaration/).
} 
Although the countries under consideration differ historically, culturally, and religiously in substantial ways, first and foremost in the foundational elements of their respective national mythologies, which contain the ethnic, cultural, and social elements that provide presumed legitimacy to populist claims, the role assumed by religion in the political claims of the western populist right may provide elements for understanding the rise of a novel transnational religious right.

The resemblance of the far-right populist attitude of prominent political figures in the U.S. and in Italy is striking in several regards. First of all, in the behavior of the abovementioned party leaders when confronting various aspects of the national and international political realm. One of the most evident common characteristics is the contrast created by the profession of a devout Christian faith and the harsh rhetoric and policy proposals reserved for the immigration emergency involving both the United States and the southern European continent.

The second, major element in common, which strongly facilitates the creation, albeit at the mainly symbolical, of a western religious rightwing network, is the insistence on the defense of constitutional individual rights against an allegedly overbearing state apparatus or central government. This defense is operated, as claimed, in the interest of the people; a category to which, however, only citizens possessing specific ethno-cultural traits can aspire to belong.

Western populist rightwing actors on both sides of the Atlantic Ocean found in the supposed clash between public good and constitutional rights the occasion to consolidate their image as defenders of an imperiled Christian identity, and to legitimize their authoritarian, nativist, and populist claims. Their growing electorate, Christian in name only, is proving willing to accept their narrative and to advance their agenda. 
References

Agi 2019. "Meloni: 'Difenderemo Dio, patria e famiglia e fatevene una ragione." $A G I$, https://www.agi.it/politica/meloni_dio_patria_famiglia_centrodestra-6392824/news/2019$10-19 /$.

An. C., 2019. "Politica e religione: quando Salvini cerca la benedizione dall'alto." I/ Sole 24 Ore, https://www.ilsole24ore.com/art/politica-e-religione-quando-salvini-cerca-benedizionedall-alto-ACoZKUd.

Barnes, Robert, 2021. "Supreme Court strikes another pandemic-related restriction on religious " Wervices." Washington Post, https://www.washingtonpost.com/politics/courts_law/supreme-court-california-coronaviruschurch/2021/04/10/182faec2-99e8-11eb-962b-78c1d8228819_story.html.

Baumgardner, Paul. "Immunizing the Flock: How the Pandemic Court Rewrote Religious Freedom." Laws, vol. 10, n. 1, 2021, pp. 1-11, DOI: https://doi.org/10.3390/laws10010012.

Betz, Hans-Georg. Radical right-wing populism in Western Europe. Basingstoke: Macmillan, 1994.

Betz, Hans-Georg, and Johnson, Carol. "Against the Current-Stemming the Tide: The Nostalgic Ideology of the Contemporary Radical Populist Right." Journal of Political Ideologies, n. 9, 2004, pp. 311-327.

Buchanan, Brian J., 2021. "Covid-19 and the First Amendment: A running report (Feb. 9)." The Free Speech Center, https://www.mtsu.edu/first-amendment/post/613/covid-19-and-thefirst-amendment-a-running-report-may-21.

CEC 2020 https://www.ceceurope.org/wp-content/uploads/2020/04/Covid-19-and-FORBFINAL-20-04-2020-.pdf.

Coakley, Amanda, 2021. "Hungary's Orbán Triest o Snatch Mantle of Christian Democracy." Foreign Policy, https://foreignpolicy.com/2021/08/03/hungary-orban-fidesz-christiandemocracy-right/.

Colaianni, Nicola. "Libertà di culto ai tempi del coronavirus." Stato, Chiese e pluralismo confessionale, n. 7, 2020, pp. 25-40, DOI: https://doi.org/10.13130/1971-8543/13252.

Cremer, Tobias. "A Religious Vaccination? How Christian Communities React to Right-Wing Populism in Germany, France and the US." Government and Opposition, 2021, pp. 1-21., DOI: 10.1017/gov.2021.18. 
Dudas, Jeffrey R. "In the Name of Equal Rights: "Special" Rights and the Politics of Resentment in Post-Civil Rights America." Law \& Society Review, vol. 39, n. 4, 2005, pp. 723758.

Edgell, Penny. "An Agenda for Research on American Religion in Light of the 2016 Election." Sociology of Religion, vol. 78, n. 1, 2017, pp. 1-8.

Gearan, Anna, Lena H. Sun, Josh Dawsey, and Michelle Boorstein, 2020. "Trump tells states to let houses of worship open, sparking cultural and political fight over pandemic restrictions." The Washington Post, https://www.washingtonpost.com/politics/trump-tells-states-to-lethouses-of-worship-open-sparking-cultural-and-political-fight-over-pandemicrestrictions/2020/05/22/1ab1c160-9c57-11ea-ad09-8da7ec214672_story.html

Giebler, Heiko, and Annika Werner. "Cure, Poison or Placebo? The Consequences of Populist and Radical Party Success for Representative Democracy," Representation, vol. 56, n. 3, 2020, pp. 293-306, DOI: 10.1080/00344893.2020.1797861.

Gjelten, Tom, 2020. "President Trump Sides With Churches Asserting A Right To Reopen." NPR, $\quad$ https://www.npr.org/sections/coronavirus-liveupdates/2020/05/23/861386816/president-trump-sides-with-churches-asserting-a-right-toreopen.

Glendon, Mary Ann. Rights talk: The impoverishment of political discourse. New York: Simon and Schuster, 2008.

Gorski, Philip S. "Why evangelicals voted for Trump: A critical cultural sociology." American Journal of Cultural Sociology, vol. 5, n. 3, 2017, pp. 338-354.

Gorski, Philip S. "Christianity and Democracy after Trump." Political Theology, vol. 19, n. 5, 2018, pp. 361-362.

Guolo, Renzo, Chi impugna la croce. Lega e Chiesa. Bari-Roma: Laterza, 2011.

Jelen, Ted G. "Political Esperanto: Rhetorical Resources and Limitations of the Christian Right in the United States." Sociology of Religion, vol. 66, n. 3, 2005, pp. 303-321.

Jelen, Ted G. et al. "Freedom of Religion and Freedom of Speech: The Effects of Alternative Rights Frames on Mass Support for Public Exemptions." Journal of Church and State, vol. 60, n. 1, 2018, pp. 43-67.

Khurana, Mansee, 2020. "The right to worship: Church and state clash over religious services in the coronavirus era." NBCNews, https://www.nbcnews.com/politics/politics-news/rightworship-church-state-clash-over-religious-services-coronavirus-era-n1201626.

Kovács, Kriszta, 2021. "Hungary and the Pandemic: A Pretext for Expanding Power." Verfassungsblog, https://verfassungsblog.de/hungary-and-the-pandemic-a-pretext-forexpanding-power/, DOI: 10.17176/20210311-154209-0. 
Lamour, Christian. "Orbán Urbi Et Orbi: Christianity as a Nodal Point of Radical-Right Populism." Politics and Religion, 2021, pp. 1-27., DOI: 10.1017/S1755048321000134.

Lewis, Andrew R. The rights turn in conservative Christian politics: How abortion transformed the culture wars. Cambridge: Cambridge University Press, 2017.

Licastro, Angelo, 2020. "Il lockdown della libertà di culto pubblico al tempo della pandemia," Consulta Online, https://www.giurcost.org/studi/licastro.pdf.

Marroni, Carlo, 2021. "Vaccini, nel fronte no-vax anche i cattolici tradizionalisti," https://www.ilsole24ore.com/art/vaccini-fronte-no-vax-cattolici-tradizionalisti-microuniverso-salvini-e-trump-AEvJJyb.

Martí, Gerardo. American Blindspot: Race, Class, Religion, and the Trump Presidency. Lanham, MD: Rowman \& Littlefield, 2019.

Mazurkiewicz, Piotr. "Religious Freedom in the Time of the Pandemic." Religions, vol. 12, n. 2, 2021, pp. 1-21, DOI: https://doi.org/10.3390/rel12020103.

Miccoli, Giovanni. “Chiesa e Lega Nord.” Studi Storici, n.1, 2012, pp. 237-244.

Migliori, Chiara M. "Donald Trump as the Champion of Freedom in the Discourse of the Religious Right and White Conservative Christian America." International Journal of Religion \& Spirituality in Society, vol. 10, n. 1, 2020, pp. 63-79, DOI: 10.18848/21548633/CGP/v10i01/63-79.

Molteni, Francesco, Riccardo Ladini, Ferruccio Biolcati, Antonio M. Chiesi, Giulia Maria Dotti Sani, Simona Guglielmi, Marco Maraffi, Andrea Pedrazzani, Paolo Segatti \& Cristiano Vezzoni. "Searching for comfort in religion: insecurity and religious behaviour during the COVID-19 pandemic in Italy." European Societies, n. 23, 2021, pp. S704-S720, DOI: 10.1080/14616696.2020.1836383.

Montgomery, Kathleen A., and Ryan Winter. "Explaining the Religion Gap in Support for Radical Right Parties in Europe." Politics and Religion, vol. 8, no. 2, 2015, pp. 379-403., DOI: $10.1017 /$ S1755048315000292.

Mudde, Cas. 2007. Populist Radical Right Parties in Europe. New York: Cambridge University Press.

Mudde, Cas, ed. The populist radical right: A reader. London, New York: Taylor \& Francis, 2016.

Mudde, Cas, 2021. "Surprised to see US Republicans cozying up to the European far right? Don't be." The Guardian, https://www.theguardian.com/commentisfree/2021/oct/15/usrepublicans-european-far-right. 
Perkins, Tony, 2020a. "De Blasio's Close Line Hangs Churches Out to Dry." www.frc.org.

Perkins, Tony, 2020b. "Outbreak: In the Early Warning Hours." www.frc.org.

Perkins, Tony, 2020c. "America's churches must be free to operate. Help us protect them." FRC Action Email.

Pew Research Center, 2020. "Americans Oppose Religious Exemptions From CoronavirusRelated Restrictions." https://www.pewforum.org/2020/08/07/americans-oppose-religiousexemptions-from-coronavirus-related-restrictions/.

PRRI Staff, 2021. "Competing Visions of America: An Evolving Identity or a Culture Under Attack? Findings from the 2021 American Values Survey." Public Religion Research Institute, https://www.prri.org/research/competing-visions-of-america-an-evolving-identity-or-a-

culture-under-attack/.

Respinti, Marco, 2016. "Il paradosso di Trump, difeso solo dai cristiani." La Nuova Bussola Quotidiana, https://lanuovabq.it/it/il-paradosso-di-trump-difeso-solo-dai-cristiani.

Rozell, Mark J. "Donald J. Trump and the Enduring Religion Factor in US Elections." In Rozell, Mark J., and Clyde Wilcox, ed. by. God at the Grassroots, 2016: The Christian Right in American Politics. Lanham, MD: Rowman \& Littlefield, 2017.

Scandroglio, Tommaso, 2021. "Gli schiavi della 'libertà' da vaccino." La Nuova Bussola Quotidiana, https://lanuovabq.it/it/gli-schiavi-della-liberta-da-vaccino.

Spuntoni, Nico, 2020. "Messe vietate, libertà religiosa l'è morta (ieri in Parlamento)." La Nuova Bussola Quotidiana, https://lanuovabq.it/it/messe-vietate-liberta-religiosa-le-mortaieri-in-parlamento.

"The Religious Freedom and COVID-19 Research Project." March 2021, updated September 2021, https://f554dbce-26b0-4a14-8ac788e0a38d4a75.filesusr.com/ugd/0fcc62_91894341a4d94e31ab049dc400517a74.pdf

Vieten, Ulrike M., and Scott Poynting. "Contemporary far-right racist populism in Europe." Journal of Intercultural Studies, vol.37, n. 6, 2016, pp. 533-540.

Walker, Shaun, 2019. "Orbán deploys Christianity with a twist to tighten grip in Hungary." The Guardian, https://www.theguardian.com/world/2019/jul/14/viktor-orban-budapest-hungarychristianity-with-a-twist.

Whitehead, Andrew L., Samuel L. Perry, and Joseph O. Baker. "Make America Christian again: Christian nationalism and voting for Donald Trump in the 2016 presidential election." Sociology of Religion, vol. 79, n. 2, 2018, pp. 147-171, DOI: https://doi.org/10.1093/socrel/srx070. 
Wodak, Ruth, Majid Khosravinik, and Brigitte Mral, eds. Right-wing populism in Europe: Politics and discourse, London: Bloomsbury Academic, 2013.

Wodak, Ruth. The politics of fear: What right-wing populist discourses mean. London: Sage, 2015.

Zambrano, Andrea, 2021. "Pandemia, quei pretesti per colpire la fede cattolica." La Nuova Bussola Quotidiana, https://lanuovabq.it/it/pandemia-quei-pretesti-per-colpire-la-fedecattolica. 